\title{
A LINGUAGEM FOTOGRÁFICA NO ISLÃ
}

\author{
Francirosy Campos Barbosa Ferreira *
}

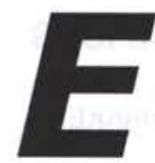

ste artigo discute a relação dos muçulmanos com a imagem fotográfica. A intenção é aproximar o nosso mundo ocidental à lógica islâmica sobre a representação da imagem, isto porque, na religião islâmica o culto à imagem é proibido: não se deve cultuar o que Deus criou. De acordo com Hanania (1999: 15), o espírito desta interdição islâmica em face da representação de formas é que, teoricamente, no Dia do Juízo, as imagens deverão ser ressuscitadas por seu autor. Mas, e a fotografia? Muito embora ela se constitua como um modelo de representação, não podemos descartá-la totalmente do contexto islâmico.

No período do profeta Muhammad (Maomé), século VII, o grande perigo para os adeptos ao Islã era o culto às esculturas, estátuas de bronze. A imagem figurativa apresentava um impedimento, pois esta representava a criação divina. Não se deve copiar o que Deus criou, pois tudo o que ele fez (faz) é perfeito, na lógica islâmica.

Para encontrar respostas a essas limitações, fui buscar em um determinado grupo - os muçulmanos do Brás em São Paulo -, elementos que apontassem a relação estabelecida pelos muçulmanos e as suas fotografias, já que essas podem também revelar imagens de corpo inteiro e, portanto, são figurativas. Esse grupo de muçulmanos é constituído, em sua maioria, por libaneses e descendentes que residem e trabalham no bairro do Brás.

\section{OS MUÇULMANOS DO BRÁS}

O meu primeiro contato com os muçulmanos foi quando visitei a Mesquita Brasil no bairro do Cambuci. Foi um misto de surpresa e de satisfação. A surpresa deuse por conta do chá oferecido em comemoração ao dia das mães, para o qual fui convidada pela coordenadora do grupo das mulheres. Nesse primeiro encontro, a ansiedade foi grande. Aguardava eu uma recepção sem graça, onde as muçulmanas iriam aparecer de véu negro, cobertas dos pés à cabeça. Ao contrário do que imaginava, encontrei muitas mulheres lindamente vestidas, com seus véus (hijab) combinando com suas roupas. Estar bem vestida significa - além de combinar as cores geralmente em tons pastéis ou ultra coloridos das roupas, saias e blusas - estar com os véus colocados de maneira a não mostrar um fio de cabelo e preso por uma presilha abaixo do queixo. Os véus brancos são os mais usados, já que branco combina com qualquer cor, mas cores como rosa, cinza, verde, lilás são comuns de serem vistas, além dos véus estampados e coloridos. Alguns, presos por tiaras de pérolas. Dependendo da ocasião, as roupas são mais ou menos sofisticadas, isto é, têm mais ou menos detalhes, podem os véus acompanhar a capa longa, tipo sobretudo que vestem as muçulmanas com ou sem bordado.

É nos véus (Ferreira, 2001) que as muçulmanas capricham, eles dão o tom da beleza, complementam a vestimenta, deixando as mulheres ainda mais bonitas. Muitas delas fazem uso de uma maquiagem leve, de jóias, e de roupas que contêm brilhos. As festas das quais participei, todas no horário da tarde -, não inibiam essas mulheres de exporem os seus brilhos, os seus véus de seda coloridos ou de uma única tonalidade. A vaidade é um componente importante a ser observado, elas se enfeitam para serem vistas entre elas. Cada uma observa como a outra está vestida. Muitas, em algumas ocasiões, perguntavam-me se estavam bem, isto é, se estavam bonitas. Cabe ressaltar, que a vaidade aqui expressa, não denota os mesmos parâmetros das não-muçulmanas; para elas, a vaidade é estar bonita para o marido, e, quando estão entre amigas, ocasião em que podem ser vistas e elogiadas também.

Surpreendi-me com a beleza, com o jeito festivo e respeitoso de se cumprimentarem. Não havia presença masculina, a não ser os garçons que discretamente serviam refrigerantes e $\operatorname{sucos}^{1}$ e retiravam-se. Ouvimos algumas palavras do xeque (líder religioso). Este leu uma surata, - capítulo do Alcorão-, em árabe que, segundo uma informante, falava sobre a mulher. Afinal, a festa era delas.

Nesse encontro, pude conversar com algumas senhoras que, a princípio, acharam o tema sobre "imagens", "fotografias", interessante, mas, em seguida, não aceitaram dar continuidade à pesquisa. Fui então apresentada ao grupo de Magda, que, na época, era estudante de Ciências Sociais, e que reside no bairro do Brás. Seu grupo demonstrou uma б́tima receptividade, possivelmente pelo fato de ela ter-me apresentado como aluna da mesma Universidade que freqüentava. Enquanto ela falava sobre as mulheres e sobre o bairro do Brás, eu construía uma imagem mental, em que as mulheres apareciam com véus longos e pretos, 
reservadas, completamente fechadas em seu meio familiar.

Em alguns momentos, interrompia minhas imagens mentais para observar o chá, a conversa amena e a comida maravilhosa que era servida. $\mathrm{O}$ bolo de semolina, dourado e açucarado e com calda, deixando-o ainda mais doce; as esfihas abertas de carne e de escarola tinham o cheiro típico da comida árabe, um aroma especial das suas próprias especiarias. A mesa era disposta de maneira a ter os salgados todos juntos e da mesma forma os doces e, para completar, muitas frutas.

Neste dia aprendi que o árabe (e aí, independe se é muçulmano ou não) adora ver os outros comerem, quanto mais melhor. É indelicado não aceitar comida quando é oferecida. Algumas vezes fui - convida a jantar ou almoçar nas casas de algumas pessoas. Dependendo da casa temse mais de um tipo de carne; comida brasileira só às segundas: arroz, feijão, bife, salada; nos outros dias da semana só comida árabe: abobrinha recheada, pimentão recheado, hummus, tabule. A sobremesa também é variada e como de costume, bem doce. Para finalizar, um bom café árabe, com borra como pede a tradição e com pistache, aprovado!

Todas as mulheres presentes à mesa foram receptivas e aceitaram ser visitadas por mim durante o tempo de pesquisa. Esse primeiro momento foi o de receber e ser recebida, recolher informações necessárias para iniciar a pesquisa naquele momento a fim de tentar um "gancho" para pensar as fotografias, pois acreditava serem elas - as fotos -, a fonte para compreensão daquele grupo muçulmano.

\section{A CASA DE MAGDA: AS PRIMEIRAS FOTOGRAFIAS}

A primeira casa que visitei foi a casa de Magda, na época com 20 anos, casada, residente do bairro do Pari, ao lado do bairro do Brás, onde há uma concentração grande de lojas de imigrantes libaneses. Ela foi uma das pessoas mais importantes naquele início de pesquisa, pois me introduziu na cultura árabe e na religião
Islâmica. Dois elementos fundamentais para pensar o quanto uma religião está presente em uma cultura, e o quanto uma cultura está presente em uma religião.

Esse primeiro diálogo foi sendo construído a partir das fotografias que ela me mostrava. A primeira delas, logo despertou minha curiosidade: era uma foto em que Magda, usando o véu, está abraçada com sua mãe, que não o usa. A primeira questão que surge é: como uma geração mais velha concebe a religião islâmica de forma completamente diferente de uma geração mais nova? O que o véu possui que outros elementos não têm? Por que a mãe está vestida diferentemente da filha? Qual a fronteira que o hijab estabelece; o que ele revela e o que ele oculta?

Para pensar sobre tais questões, utilizo - conceito de tradição inventada elaborado por Hobsbawn. Para ele, "tradição inventada é um conjunto de práticas, que são reguladas por regras tácita ou abertamente aceitas; tais práticas, de natureza ritual ou simbólica, visam inculcar certos valores e normas de comportamento através da repetição, isto implica uma continuidade em relação ao passado" (1994: 9). Como estas regras não foram passadas de uma geração para outra, algumas pessoas, assim como Magda, Malac, Afaf $^{2}$ e Paloma, começaram a sentir a necessidade de conhecer a religião praticada pelos seus parentes do Líbano, reinventando a tradição no seu grupo e fazendo com que outros muçulmanos não praticantes também começassem a vivenciar mais intensamente a religião.

Magda já havia apontado a questão da transformação do seu grupo, pessoas que não praticavam o Islamismo, que apenas se denominavam muçulmanos, mas sem saber ao certo o que isso significava (Latif, 1997). A retomada da religião, para essas pessoas, passou a ser um elemento importante para se pensar sobre tradição inventada, ou, nos termos propostos por Manuela Carneiro da Cunha, "A cultura original de um grupo étnico, na diáspora ou em situações de intenso contato, não se perde ou se funde simplesmente, mas adquire uma nova função, essencial e que se acresce às outras, enquanto se torna cultura de contraste...." (1987: 99). ${ }^{3}$
Nesse dia, pude ver muitas fotos, foram horas vendo imagens que pouco compreendia, algumas mais curiosas do que outras. $\mathrm{O}$ que ficou de tal encontro foi o relato da história de Magda Latif. Sua história é a seguinte: ela não foi educada na religião islâmica pelos seus pais, que são muçulmanos. Sua história de conversão se iniciou no dia em que ela estava no Líbano e começou a se perguntar sobre o motivo de algumas mulheres estarem de véu e outras não. Uma parente que usava o véu disse a ela que se tratava da religião dos muçulmanos, sobre a qual Magda sabia muito pouco, ou quase nada. A menina de 14 anos começava a observar todos os muçulmanos praticantes a sua volta, um funcionário da loja de seu pai, que parava cinco vezes ao dia para rezar.

Foi aí que ela pediu ao pai que lhe pagasse um professor de árabe, e seu interesse foi aumentando cada vez mais. Seu processo de conversão foi demorado, e ela queria conhecer mais sobre a religião dos seus antepassados. Nem que para isso ela tivesse que brigar com seu pai que era contrário à sua decisão de conversão. A mãe, que já era separada de seu pai, não pôs restrições à vontade da filha, sempre apoiou seu desejo, com a ressalva que ela tivesse certeza do que queria para a sua vida. Para Fátima, mãe de Magda, não se poderia simplesmente pôr o véu e depois de alguns meses decidir por não mais querer usá-lo.

Para chegar a usar o hijab, começou por transformar seu guarda-roupa: nada de biquínis, shorts (só dentro de casa); agora vestia-se com saias compridas e blusas de mangas longas. Não só as roupas foram sendo mudadas, mas o conhecimento em relação à religião que passaria a abraçar. Participava agora das aulas de religião dadas pelo xeque no Centro Islâmico, passando a ser leitora do Alcorão. Decidiu espontaneamente colocar o véu quando saía para ir ao aeroporto buscar alguns parentes que chegariam do Líbano. A partir desse dia sua imagem perante o grupo modificou-se: passou a ocupar um outro estatuto, que é a imagem de uma jovem religiosa, respeitada por todos, pela inteligência e capacidade de articular e passar adiante os ensinamentos do Islamismo. 
Durante a conversa, foi possível ver fotos de parentes que também tinham histórias parecidas. Algumas fotos que me chamaram a atenção foram as do seu casamento, marcado por um ritual muçulmano, pois casou-se com um muçulmano, que assim como Magda vive intensamente a religião: acredita e segue o Arkan-ul-Islam, os cinco pilares do Islã, que são os cinco deveres mais importantes. O primeiro é o Shahada, ou declaração de fé. O segundo, Salat, prega que os muçulmanos devem rezar para Deus cinco vezes por dia, entre a aurora e o anoitecer. O terceiro é Zakat, ou doação de esmolas, a prática da caridade. O quarto é o Sawm, o jejum durante o mês do ramadã. O quinto é Hajj, a peregrinação a Meca durante o $12^{*}$ mês do ano islâmico. Esses deveres ensinam disciplina, pontualidade e devoção a Alá (Shahrukh:1999).

\section{POR QUE PRODUZIR IMAGENS?}

"É que chegava o momento onde não bastaria 'falar e discursar' em torno do homem, apenas 'descrevendo-o'. Haver-seia de 'mostrá-lo', 'expô-lo', 'torná-lo visivel' para melhor conhecê-lo, sendo a objetividade de tal empreendimento não mais ameaçada pelo 'visor' da câmera do que pelo caderno de campo" (Margaret Mead, In: Samain: 1995).

As imagens produzidas por antropólogos ocupam hoje um espaço significativo, uma vez que elas não são meras ilustrações, mas interpretações do que é observado. A imagem é considerada como objeto e método antropológico, não só como suporte da pesquisa, mas fonte para a própria pesquisa. $\mathrm{O}$ reconhecimento dessa área vem sendo conquistado há algum tempo por grupos como os das universidades de Porto Alegre, Santa Catarina, Rio de Janeiro, São Paulo, Campinas, os quais têm demonstrado o quanto o terreno da imagem é fértil. Em outras palavras, a imagem, como bem apontou Ferraz (1999: 188), potencializa o diálogo etnográfico de modo a nos auxiliar na compreensão do processo estudado. (grifo meu)

Em "Ver" e "Dizer" na tradição etnográfica: Bronislaw Malinowski e a fotografia, Etienne Samain aponta que as fotografias produzidas por Malinowski funcionam como ponto de partida, desencadeadoras, molas inspiradoras do texto: a fotografia apresenta, representa. É nesse sentido que faço as minhas fotos, na tentativa de produzir as inquietações, a partir do meu lugar como pesquisadora que "faz" fotografias também com a intenção de ampliar o diálogo entre pesquisador e fotografados.

De certa forma, todo esse fortalecimento da área visual contribui, e muito, para a pesquisa que desenvolvi no campo da imagem. Acredito que ao produzir minhas próprias imagens construo minhas interpretações do grupo pesquisado. Além da capacidade perceptiva, entram em jogo o saber, os afetos, as crenças, que por sua vez, são muito modelados pela vinculação a uma região da história - a uma classe social, a uma época, a uma cultura -, (Aumont, 1990). O olhar através da câmera já está selecionando algo no objeto observado. Ao selecionar também interpreta, descreve, contextualiza.

Quando produzo uma imagem estou inserindo meu olhar, minha interpretação, minha percepção de determinado evento. O registro fotográfico não está isento de interpretação seja do fotógrafo, seja do fotografado. Corroboro a expressão de Geertz (1989) de descrição densa, na qual o papel do antropólogo é inscrever o discurso do nativo, é explicar explicações de explicações; piscadelas de piscadelas. $\mathrm{O}$ autor considera que a descrição já é em si mesma densa, e a densidade implica a interpretação. Isto fortalece a idéia de que a pesquisa etnográfica é mais do que uma coleta de dados, mas sobretudo, concretizase em uma interpretação. Observando as imagens fotográficas de antes e depois do uso do véu por algumas muçulmanas, podemos encontrar uma realidade completamente distinta uma da outra. Há 12 anos, quando a maioria das mulheres ainda não usava o hijab, era possível encontrá-las em ambientes de festa junto com os homens. As roupas usadas eram diferentes das que usam hoje em dia. É possível perceber vários sinais de mudança de comportamento, não só na vestimenta, mas no próprio ambiente social em que vivem.

As fotografias que foram produzidas pelas muçulmanas e que não podem ser reveladas, pelo fato delas não estarem de véu, passou a ser um ponto importante de reflexão e de desejo de também começar a fotografar.

Produzir imagens faz parte desse trajeto de construção de uma descrição densa, pois imagens produzidas dos e pelos muçulmanos, pude ir além e perceber também nas fotografias que faço uma descrição a partir do meu olhar, que carrega potencialidades próprias, como registrar, documentar, estabelecendo assim uma memória do evento vivido, conforme destaca Caldarola (1988): "nós etnógrafos, construímos fotografias para fazê-las refletir e coincidir com representações etnográficas de eventos sociais, por mais parciais e incompletas que sejam (...) escolhemos e definimos o tema; decidimos sobre momentos e locais particulares, selecionamos a perspectiva, o enquadramento ..."

Em se tratando de um grupo muçulmano, o momento e os locais particulares nem sempre são escolhidos pelo etnógrafo, posto que há uma série de restrições na hora de produzir uma imagem. A primeira delas é não fotografar uma mulher sem véu. Como resolver tal dilema em uma festa de mulheres? Quando as mulheres estão reunidas, retiram o hijab, passando a ter uma imagem que não pode ser reproduzida pela pesquisadora, mas no entanto, pode ser registrada por elas. Uma mulher só pode fotografar dentro da mesquita se estiver usando o véu, e no lugar reservado às mulheres. Os limites caminham junto com as potencialidades.

Para iniciar essa reflexão privilegiei dois momentos vivenciados no fazer imagens junto aos muçulmanos que residem no bairro do Brás em São Paulo: o primeiro, um moulid, chá oferecido por uma das mulheres às suas amigas e parentes (todas mulheres); o segundo, um dia de oração na mesquita Brasil. Abro um parêntese aqui para informar que o fato de ser uma pesquisadora, e portanto, mulher, o acesso aos espaços femininos é muito maior e bem mais fácil, já que entre os muçulmanos as mulheres tendem a se agrupar. 


\section{MOULID - UM CHÁ COM AS MULHERES DO BRÁS}

No Brás é muito comum as mulheres se reunirem para um chá. O moulid é um desses, entretanto, ele possui uma conotação diferente por ter sentido religioso. É como se estivesse pagando uma promessa: fez-se um pedido ao profeta e este atendeu. Foi o caso de Gineme que ofereceu um moulid em sua casa, aproveitando para comemorar o aniversário de dois anos de sua filha. No início do chá as mulheres lêem trechos do Alcorão, cantam músicas que falam de Deus, e depois o chá torna-se igual a todos os outros: com muita comida, dança e alegria.

Nesse moulid percebi a primeira limitação de fazer imagens, as mulheres ficam sem véu, por estar dentro de casa, e as fotos sem o uso do véu não são autorizadas, contudo, não significa que elas não as façam. As muçulmanas do Brás só permitem serem fotografadas usando seu veú.

Com o tempo fui percebendo que esta exigência fazia parte não só da construção da noção de pessoa (Mauss, 1974), mas também da fabricação da identidade e da auto-imagem do grupo (EvansPritchard,1978); (Caiuby Novaes, 1993). A fabricação da identidade está ligada à reinvenção da tradição como aponta Hobsbawn (1994).

Percebi a necessidade de se definir quem é e quem não é muçulmana, neste ponto a vestimenta islâmica, por ser visível, aponta as mulheres que são muçulmanas, invocando uma maior visibilidade do grupo face a minoria que representa aqui no Brasil. (Caiuby Novaes, 1993: 25). Da mesma forma que fabricam a identidade, também constroem sua auto-imagem, que é um conceito apontado como sendo relacional e constituído historicamente, através desse sinal diacrítico, que é o hijab.

Como em toda reunião de mulheres, a música dá o tom da alegria, seja elas cantando ou ouvindo um aparelho de som. Quando cantam e dançam tiram os véus, e as imagens cessam, pois isto inibe os movimentos. Participar de uma festa dessas é contagiante, é bonito ver, é envolvente. Fazer imagens é complicado nesse momento, ao final elas posam com alegria para fotos, arrumam-se, isto é, colocam os véus. É nesse momento que se dá a construção da noção pessoa: Eu sou fulana de tal. As mulheres do Brás fazem questão de serem fotografadas de hijab.

Nesse período de busca do conhecimento por parte desses muçulmanos que passaram muitos anos sem a prática cotidiana da religião, eram apenas muçulmanos de nome e não praticantes. É muito sério a retomada de alguns valores como o próprio uso do véu, esses acabam sendo mais exigentes do que seriam em seu país de origem. Se para eles é indiscutível que uma mulher não deve aparecer sem o seu véu em uma foto, ou em algum vídeo, em outros lugares pode ser que não haja essa mesma regra.

\section{O VÉU - HIJAB}

O hijab separa o que é oculto do que pode ser revelado, de certa forma vai definindo a própria produção imagética a ser construída. As imagens produzidas são

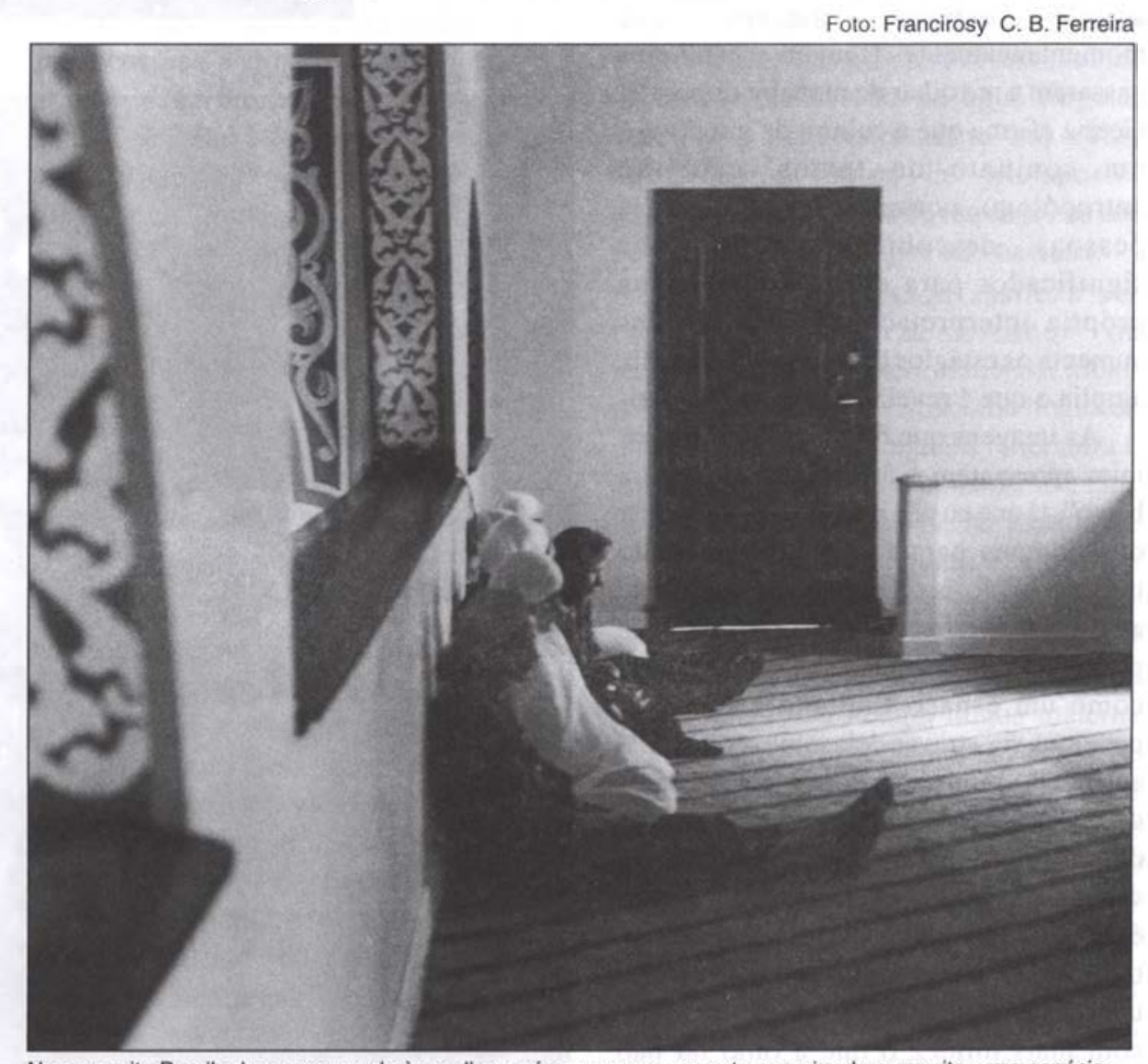

Na mesquita Brasil o lugar reservado às mulheres é pequeno, e na parte superior da mesquita, uma espécie de mezanino coberto de tapetes.

encaminhadas pelo desejo da construção da imagem que eles querem mostrar aos outros.

No meu trabalho, o primeiro limite encontrado foi produzir fotografias das mulheres sem o véu. Entender essa restrição cabe ao antropólogo, a partir do contexto em que se fala para chegar a sua interpretação.

Nesse momento, em que a religião está fortemente em discussão no cerne dessa comunidade, como uma retomada não só do sentido religioso, mas também da retomada de valores culturais, antes também deixados de lado. $\mathrm{Na}$ busca da identidade cultural, como diria Hobsbawn,a tradição inventada -, passou a ter sentido marcar a diferença; acredito até que seja um momento ainda de transição em que os valores estão expostos ao extremo. Há uma exotização da cultura. Sendo assim, o uso do véu é fundamental e pode ser visto como um divisor de águas: de um passado afastado da prática Islâmica para um período de aproximação à religião, mudando-se radicalmente a conduta

Foto: Francirosy C. B. Ferreira 
adotada anteriormente.

Corroboro a idéia de Nabhan (1996) que a religião islâmica está servindo para este grupo de libaneses e seus descendentes como uma maneira de uni-los, de aproximá-los.

\section{A "BRIGA DE GALOS" DA IMAGEM ${ }^{4}$}

Quando escolhi fotografar o dia de oração ${ }^{5}$ dos muçulmanos, às sextas-feiras, não previa a necessidade de ficar em um lugar reservado às mulheres e fazer uso do hijab. Na "briga de galos" da imagem, eu me colocava como pesquisadora que pretendia fazer imagens da oração dentro da mesquita. "Se em Bali, ser caçoado é ser aceito"(Geertz,1989), na mesquita ser mulher é estar de véu e estar em seu lugar é ser aceita. Para fazer as fotografias precisei ficar no lugar reservado às mulheres e usar véu. A partir do momento em que estive nesse lugar e usando véu, passei a ser reconhecida como pertencente àquele espaço, mesmo que momentaneamente. Homens e mulheres passaram a me olhar de maneira diferente. Geertz afirma que a cultura de um povo é um conjunto de textos, cabe ao antropólogo, portanto, ler através das pessoas, descobrir o acesso aos significados para então construir sua própria interpretação. Fazer imagens aumenta os estágios da minha observação, amplia o que é revelado e o que é oculto.

As imagens que foram produzidas por mim apresentam o ângulo "de cima para baixo”, já que eu não poderia me aproximar dos homens para fotografá-los, sendo mulher. A foto da janela da mesquita apresentando o formato de um templo, cuja ponta está direcionada a Deus - é aqui como um espaço limitado à imagem: podemos ver através dela muito pouco. Ela apresenta, representa o que conhecemos dos muçulmanos, apenas uma fresta, e a dificuldade que temos de enxergar além das imagens que chegam até nós; para ver é preciso encontrar essas frestas que abrem o campo da nossa visão, como a lente de uma câmera que é utilizada para reproduzir com mais nitidez o que a olho nu não vemos tão nitidamente.
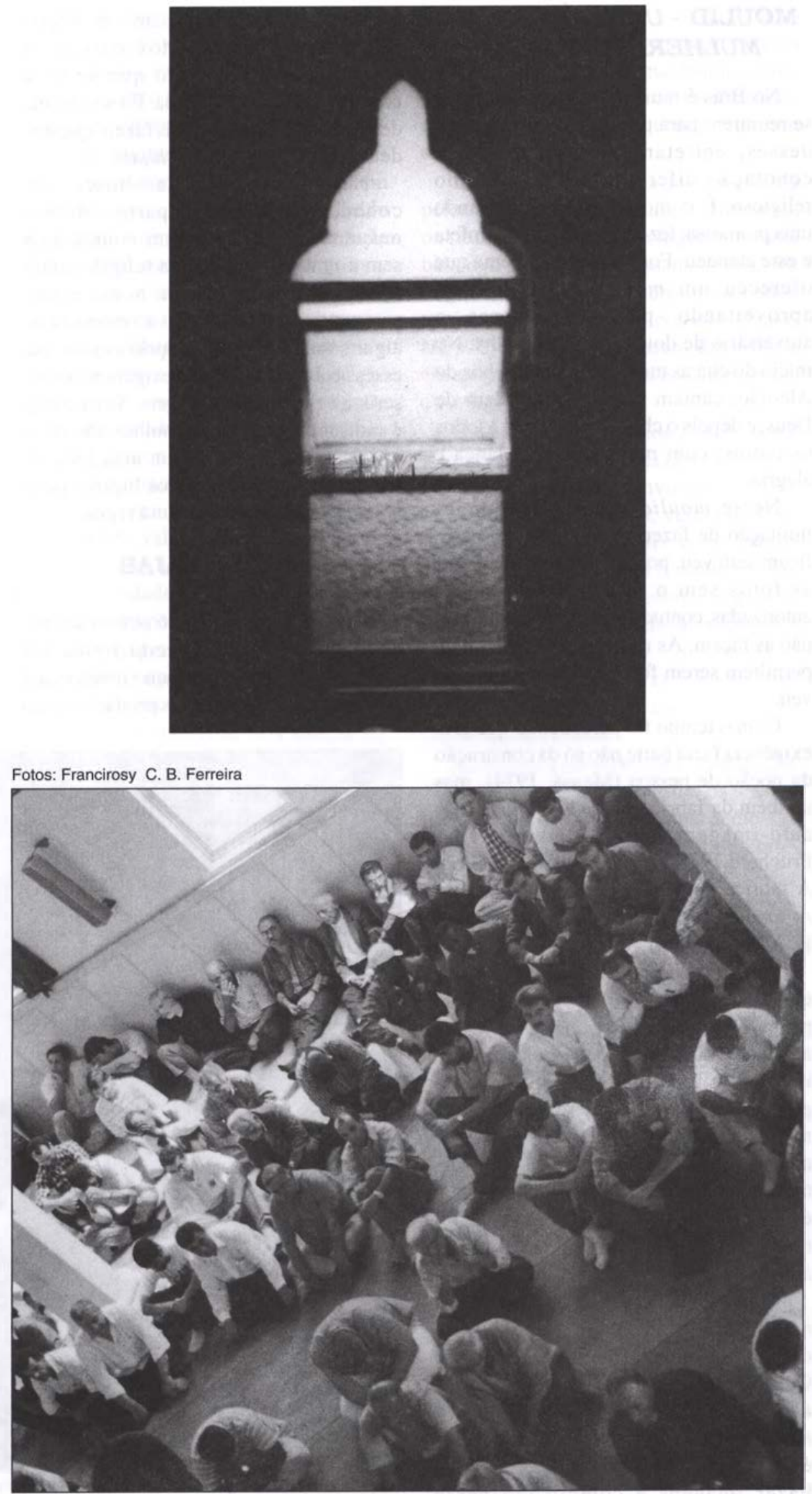

Foto tirada do alto, onde vemos os homens sentados ouvindo o sermão; raramente olhavam para mim. ${ }^{6}$ 


\section{A FOTO COMO CÓPIA DO REAL}

Este texto teve como propósito, guiar o leitor, isto é, aproximá-lo do mundo muçulmano e de pôr em pauta a questão do poder que a imagem carrega em seu cerne. Poder este que nos remete a Michel Taussig, quando este discute o poder que há na cópia, no poder que existe na coisa representada. A cópia é freqüentemente mais poderosa, mais expressiva que o próprio real, porque ela está coberta de significado, talvez por isso, o cuidado em fotografar determinadas pessoas e determinados lugares. Qual seria o uso social dessas imagens? Quem as veria, no caso das muçulmanas?

Tecnicamente falando, a fotografia produzida já é passado constituído. Diante dela podemos fixar o nosso olhar e voltar (ao passado, ao que já se foi) a ela quando quisermos. É um elemento que nos remete constantemente a um passado próximo ou distante.

As imagens produzidas por nãomuçulmanos carregam esta potencialidade máxima da foto, é preciso ter cuidado com o que está sendo mostrado, e para isto acontecer, as restrições se fazem necessárias para o controle da imagem que é produzida.

Para a pesquisa que realizava naquele momento, as imagens produzidas na mesquita trouxeram um novo olhar, era um passo à frente. Estando atrás da câmera, o enfoque era outro, e o diálogo a ser construído também. Registrava algo que para eles têm dois sentidos: é perigoso, quando é utilizado de maneira indevida, como as imagens estereotipadas produzidas por alguns jornalistas. As mulheres, muçulmanas ou não, devem cobrir-se quando entram em uma mesquita. Homens e mulheres devem tirar seus sapatos e sentar-se separados devido a oração que para ser correta deve permitir que homens e mulheres se curvem. A atitude é de total respeito; fotografar ou filmar só com autorização, e sendo mulher deve-se estar próximo a elas, nunca no mesmo ambiente dos homens.

Com o tempo, conceder uma foto é estar de acordo com minha presença, eu deixo de ser invasora da sua privacidade para ser parceira das conversas, das festas, das cerimônias, mesmo não sendo uma delas, mas alguém que está o tempo todo questionando e ouvindo as várias explicações sobre determinados eventos. Alguém que pratica verdadeiramente a alteridade, o reconhecimento do outro como diferente.

Mas, por outro lado, há uma boa discussão a ser aprofundada: qual é o poder que há na cópia, na representação do real? Refiro-me ao significante e ao referente, isto é, as fotos e os muçulmanos, que ocasionam, como foi dito anteriormente, uma relação simbólica, metafórica.

As fotografias são significantes, são veículos que transportam significado, que é a idéia da coisa representada (Aumont,1990; Leach,1990). O poder da cópia pode estar no cerne desta discussão. O que a fotografia carrega dos muçulmanos que a torna proibida para algumas pessoas? Se o próprio muçulmano faz sua foto, ele sabe de que maneira pode ser utilizada aquela imagem, por outro lado, um nãomuçulmano, não saberia fazer uso correto dessas imagens. $\mathrm{O}$ que percebo é que a fotografia de uma mulher sem véu poderia ser vista por outras mulheres, mas jamais por homens, contudo, não é qualquer mulher que pode ter acesso a essas fotos.

Se a fotografia desempenha um papel simbólico na legitimação da família como afirma Moreira Leite (1993), no caso das fotos dos muçulmanos, ela legitima o ser muçulmano, se para sentir-se muçulmano algumas mulheres fazem uso do véu, portanto é esta imagem que deve ser vista, é ela que carrega o símbolo visível de sua identidade.

A primeira limitação no início da pesquisa era informá-las se haveria homens na banca de mestrado. Informação preciosa para ter acesso às fotografias de algumas mulheres, mesmo usando véu.

De certa forma, ainda acho essa uma questão a ser explorada, pois o Islamismo provocou de certa forma uma arabização menor ou maior em alguns países, talvez por ser de origem árabe, e ter o livro sagrado, o Alcorão, escrito nesta língua, obrigando de certa forma, aos muçulmanos convertidos, a aprender a ler e adotar alguns costumes próprios desta cultura.

Se por um lado o fazer imagens requer um cuidado com o que não pode ser mostrado, retratado, - por exigência dos pesquisados -, por outro lado abre uma porta para se pensar no não-visível, aquilo que não se deixa fotografar. A foto como cópia que carrega significados que aparentemente estão ocultos, mas que se revelam no ato de olhar. Para esta comunidade, que nos últimos anos tem se aproximado ainda mais do Islã, o que esconder, o não revelar está relacionado a não voltar ao passado. Passado este sem a prática da religião, sem a adoção do véu como convicção religiosa.

Nesses exercícios de produção de imagens fotográficas, olhar e fazer caminham juntos, foi olhando que aprendi fazer, fazendo aprendi olhar. Produzir imagens é sempre um movimento de ir e vir, é produzir significados, ou simplesmente reproduzi-los. Ainda palimpsestos.

\section{CONCLUSÃO}

Se, como descreve Moreira Leite (1993), "Os limites de espaço e tempo social e a ordenação simbólica do mundo permitem conhecer o significado do contexto imediato das imagens fotográficas, que são produzidas através de um ritual ou por condensações rituais do universo examinado... A descrição e a interpretação do conteúdo e da expressão da fotografia permitem, por sua vez, a compreensão de seus elementos constitutivos".

Foi observando as fotografias apresentadas a mim pelos muçulmanos que constatei mais claramente as mudanças de que eles falavam. Observei a mudança temporal. Como se vestiam antes as mulheres muçulmanas quando chegaram a São Paulo e como se vestem hoje ${ }^{7}$. Mas, a compreensão das limitações apontadas por eles, só fui perceber ao fazer imagens. Produzir imagens nesse grupo indica uma outra linguagem a ser construída, primeiro porque elas proíbem algo que elas mesmas fazem, que é fotográfa-las sem véu.

Em sendo assim, podemos verificar que as fotografias possuem uma linguagem e códigos que são diferentemente interpretados e refeitos dependendo do contexto que se insere e principalmente dos 
agentes inseridos nesses contextos: um pesquisador não pode fotografar uma muçulmana sem véu, mas quem é de dentro da comunidade pode perfeitamente fazer essas fotos.

Para finalizar, devemos considerar que nem sempre os textos dão conta de apresentar um respectivo universo. É preciso que outras contribuições se façam necessárias. A Antropologia Visual vem contribuindo para esta observação sistemática em relação às imagens (fotográficas, vídeográficas, cinema e outras mídias) dando outros enfoques às etnográficas.

Foi neste terreno que busquei me aproximar de um grupo muçulmano, muito embora tenham as fotografias algumas restrições de quem pode vê-las, reproduzilas e assim por diante. $\mathrm{O}$ maior limitador na construção dessas imagens é sem dúvida o véu islâmico. Vê-se o encoberto, mas nem por isso deixamos de lado os seus significados. A fotografia mostra-nos os vários usos e lugares nos quais as imagens podem ser construídas.

* Francirosy C. B. Ferreira é Mestre em Antropologia Social pela USP, Pesquisadora do GRAVI - Grupo de Antropologia Visual/ USP, Pesquisadora do NAPEDRA - Núcleo de Antropologia Performance e Drama, Editora da revista Cadernos de Campo.

\section{NOTAS}

1. O Islamismo proíbe a ingestão de bebidas alcóolicas.

2. Afaf faleceu em 18 de fevereiro de 2001

3.Para quem está preocupado com a construção da imagem, é preciso pensar na dinâmica que se estabelece quando uma muçulmana passa a usar o véu. Sua imagem perante o grupo muda, é motivo de orgulho para aqueles que fazem questão de ser religiosos, mas não posso deixar de considerar aqueles que não aprovam sua utilização aqui no Brasil. Foi o que aconteceu com uma das minhas informantes, de 18 anos, há quatro anos faz uso do véu, e encontrou resistências de seu pai, ele não concordava com a posição da filha, achava que não cabia mais ver mulheres cobrindo-se, que ela era jovem. $\mathrm{Na}$ sua percepção parecia mais um capricho da filha do que propriamente uma decisăo madura. As discussōes que ela conta mais parecem relatos de uma adolescente que quer viajar a sós com o namorado, mas o pai a proíbe, e aí trava-se um problema familiar insuportável. $\mathrm{O}$ apoio de seus vizinhos nesse momento difícil foi importante em sua decisão, isto ajudou a superar a decepção que estava dando ao seu pai e a sua mãe. A mãe com o tempo foi se acostumando com a decisão da filha. O que fica dessa história são as duas imagens que produz uma menina de 14 anos usando véu, a imagem de quem acha que é uma loucura tal decisăo e o apoio por parte daqueles que seguem a religiăo tradicionalmente, considerando normal tal decisão.

4. Em seu texto - "Um Jogo absorvente: Notas sobre a briga de galos balinesa" -, Clifford Geertz (1989) conta a sua experiência de pesquisa de campo em Bali, quando ele e sua esposa assistiam a briga de galos, que neste país é proibida. Quando a polícia apareceu, todos fugiram, inclusive Geertz. Isto fez com que os balineses mudassem o tipo de relação que mantinham com ele, passando de uma relação de afastamento a uma de maior proximidade.

5. A oração de sexta-feira é obrigatória aos homens e facultativa às mulheres. Neste dia havia poucas mulheres participando.

6. Em comemoração aos 500 anos do Descobrimento, a Caixa Econômica Federal fez um catálogo das imigrações no Brasil. Há fotos feitas na mesquita Brasil, mesmo lugar em que fiz minhas fotos. O que primeiro notei foi que só um homem poderia ter feito aquelas imagens, pois retratava os homens na parte de baixo em dia de oração. Dependendo de qual é a imagem, o ângulo, podemos afirmar que as fotos não poderiam ter sido feitas por uma mulher. Confirmei esta idéia quando olhei os créditos no final do catálogo.

7. É importante frisar que esta retomada da religião ou resignificação da religião neste contexto é uma peculariedade do grupo do Brás, em contrapartida temos outras comunidades como a de Săo Bernardo do Campo em que a maioria das mulheres já veio ao Brasil adotando o véu como parte de sua vestimenta.

\section{REFERÊNCIAS BIBLIOGRÁFICAS}

AUMONT, J.

(1990) A imagem. Campinas, Ed. Papirus.

CAIUBY NOVAES, Sylvia

(1993) Jogo de Espelhos. Săo Paulo, EDUSP.

CAIUBY NOVAES, Sylvia

(1996) "Um casamento no Paquistão: na captura de imagens". In: Cadernos de Antropologia e Imagem. UERJ, Nai.

CALDAROLA,V.J.

(1988) "O processo imagético como pesquisa etnográfica". In: Visual Anthropology, Vol.1, pp.433-451, Harwood
Academic Publishers GmbH.

\section{CARNEIRO DA CUNHA, M.}

(1987) "Etnicidade, da cultura residual mas irredutível". In: Antropologia do Brasil. São Paulo, Ed. Brasiliense.

EVANS-PRITCHARD, E. E. (1978) Nuer. Ed. Bras. Perspectiva.

FERRAZ, A.L.M.C.

(1999) O Velho e Novo Sindicalismo. Dissertaçăo de Mestrado em Antropologia Social, FFLCH, USP.

FERREIRA, Francirosy, C.B. (2001) Imagem Oculta - reflexões sobre a relação entre os muçulmanos e a imagem fotográfica. Dissertação de Mestrado em Antropologia Social, FFLCH, USP.

GEERTZ, C.

(1989) A Interpretação das Culturas. Rio de Janeiro, Ed. Guanabara.

GEERTZ, C.

(1994) Observando el Islam. El desarrollo religioso en Marruecos e Indonesia. Barcelona, Ed. Paidos.

HANANIA, A. R. (1999) A Caligrafia Árabe. São Paulo, Martins Fonte.

HOBSBAWN, E. \& RANGER, T. (1994) A invenção das tradições (introdução). Paz e Terra.

LATIF, Magda Aref (1997) As mulheres do Brás. (mimeo).

LEACH,E.

(1990) Cultura e comunicação. Lisboa, Ed.70.

MAUSS, $M$. (1974) "Essai sur le Don". Sociologia e Antropologia. São Paulo, EDUSP.

MOREIRA LEITE, M. L. (1993) Retratos de família. Săo Paulo, Edusp-Fapesp.

MOREIRA LEITE, M. L. (1997) "Imagem e Memória". In: Livros de Viagem. Rio de Janeiro, Ed. UFRJ.

NABHAN, N.

(1996) Islamismo de Maomé aos nossos dias. São Paulo, Ed. Ática.

SAMAIN, E.

(1995) “'Ver' e 'Dizer' na tradição etnográfica Bronislaw Malinowski e a fotografia". In: Horizontes Antropológicos. Porto Alegre, UFRGS.

HUSAIN, S.

(1999) O que sabemos sobre o Islamismo? Săo Paulo, Ed. Callis.

TAUSSIG, $M$.

(1993) Mimesis and Alterity. New York, Routledge. 